\title{
PUBLIC FINANCIAL MANAGEMENT AND CORRUPTION IN INDONESIA: A PANEL COINTEGRATION AND CAUSALITY ANALYSIS
}

\author{
Sugeng Triwibowo ${ }^{1,2 *}$ \\ ${ }^{1}$ Department of Economics, Faculty of Economics and Business, Universitas Gadjah Mada, \\ Yogyakarta, 55281, Indonesia \\ ${ }^{2}$ Department of Economics, Graduate School of International Social Studies, Yokohama National \\ University, Yokohama 240-8501, Japan
}

\begin{tabular}{|c|c|}
\hline ABSTRACT & ARTICLE INFO \\
\hline $\begin{array}{l}\text { Introduction/Main Objectives: This paper aims to examine the } \\
\text { relationship between the quality of public financial management and } \\
\text { corruption in Indonesia. Background Problems: Despite the impressive } \\
\text { progress on the quality of public financial management (PFM) after the } \\
\text { financial reforms, Indonesia is still struggling to combat corruption. This } \\
\text { raises the question of the effectiveness of the public financial reforms that } \\
\text { have been carried out in support of the eradication of corruption. } \\
\text { Novelty: This study found empirical evidence of a significant long-run } \\
\text { and causal relationship between the quality of public financial } \\
\text { management and corruption. Research Methods: This study employs } \\
\text { panel cointegration and causality analysis with panel data on the } \\
\text { Corruption Perception Index (CPI) and audit opinions for the period from } \\
\text { 2006 to } 2017 \text {. Finding/Results: This study found empirical evidence of } \\
\text { the existence of a long-run relationship between the quality of public } \\
\text { financial management and corruption and can verify the significant causal } \\
\text { relationship between them. In the long run, sound public financial } \\
\text { management could significantly encourage clean government. } \\
\text { Conclusion: The Government of Indonesia (GoI) should continue its } \\
\text { commitment to improve the management of public finances. Meanwhile, } \\
\text { the Audit Board of Indonesia (ABI) is expected to strengthen its role to } \\
\text { prevent and detect corruption, and to continuously enhance its methods } \\
\text { and capacity to improve the execution of its duties and authority. }\end{array}$ & $\begin{array}{l}\text { Article history: } \\
\text { Received } 19 \text { October } \\
2019 \\
\text { Received in revised form } \\
21 \text { February } 2020 \\
\text { Accepted } 25 \text { February } \\
2020 \\
\text { Keywords: } \\
\text { audit opinion, public } \\
\text { finance, corruption, panel } \\
\text { cointegration, causality } \\
\text { test }\end{array}$ \\
\hline
\end{tabular}

\footnotetext{
* Corresponding Author at Department of Economics, Faculty of Economics and Business, Universitas Gadjah Mada, Jalan Socio Humaniora No. 1, Yogyakarta 55182, Indonesia.

E-mail address: sugengtriwibowo@mail.ugm.ac.id 


\section{INTRODUCTION}

Corruption was accused as one of the cause of the massive financial and economic crisis in 1997/98 in Indonesia and corruption, which was a result of poor quality public and private governance, the weak legal institutions and the lack of transparency and accountability, was also the reason for the government's inability to restraint a deeper crisis (Brown, 2006). When the crisis occurred in 1997, Transparency International (TI) proclaimed Indonesia as one of the most corrupt countries in the world viewed from the rank of Indonesia's Corruption Perception Index (CPI). Indonesia ranked $46^{\text {th }}$ out of 52 countries, with a score of 2.72. (A perfect score is 10.00 , for a totally corruptionfree country). Corruption was also believed to evoke economic distortions that were partially responsible for the economic crisis and led to massive riots and governance debacles (Macmillan, 2011).

After the crisis, Indonesia committed itself to public financial reform to strengthen the quality of public financial management (PFM) and, as a part of its strategies for combating corruption (Macmillan, 2011), it established the Corruption Eradication Commission (KPK) in 2002, issued the State Finance Act in 2003, the State Treasury Act, and the State Financial Management and Accountability Audit Act in 2004. The reforms resulted in a revitalization and repositioning of the role of public auditors in public financial management, by ensuring they could exercise their function of controlling the state's financial management, through the issuance of the Supreme Audit Agency of The Republic of Indonesia (BPK RI) Act in 2006.

After almost one and a half decades of the public financial reforms, the state's financial management is heading in a positive direction, as reflected by the acquisition of audit opinions by the auditor. Based on the Audit Report from
Badan Pemeriksa Keuangan (BPK) RI (the Audit Board of Indonesia - ABI), in 2007 only seven percent of ministries and central government institutions obtained the unqualified (Wajar Tanpa Pengecualian/WTP) opinion which is the best possible audit outcome. In 2017, the number rose to 84 percent. Regional governments have also seen similar progress. In 2007 only one percent of all the local government entities examined by the BPK received the unqualified opinion, and that number increased to 70 percent in 2017. Moreover, The World Bank in May 2018 reported that Indonesia had manage to succeed in establishing a strong and reliable system of internal controls, accounting and reporting systems and procedures, internal and external audit systems with strengthened accountability and transparency.

Concurrently, Indonesia still suffers from widespread corruption. Transparency International (TI), in their report of October 2018, stated that corruption is still endemic in all three state branches; judicial, legislative and executive. In early 2019, Transparency International's Corruption Perception Index (CPI) ranked Indonesia as number 96 out of 180 , with a score of 38 points out of 100 , an increase of only one point compared to the previous year. This implies slow progress in curbing corruption. Moreover, according to the Indonesian Corruption Eradication Commission (KPK RI), the number of corruption cases handled by the KPK in 2007 was 113 , and this increased sharply to 514 cases in 2017. On average, the number of cases handled by the KPK increased by 26 percent each year over that period.

This problem of duality between the significant progress in the public financial management sector, on one hand, and the prevalence of corruption in Indonesia on the other hand, has raised a question about the efectiveness of the public financial reforms that have been carried 
out in support of the eradication of corruption. It is expected that a strong public financial management system could be deterring and detecting corruption by reducing the opportunities for fraud; pointing out the potential causes of irregularities, improving the rules and regulations and supporting appropriate disciplinary corrective actions against violators and increasing the opportunity cost of any misbehavior will also help (Dorotinsky and Pradhan, 2007).

In addition, previous empirical studies in Indonesia on the relation of the quality of public financial management reflected in the acquisition of audit opinions for government agencies' financial statements and corruption found that the audit opinions from the Audit Board of Indonesia (ABI) have no significant relation or correlation with corruption (Tehupuring, 2018; Rini \& Damiati, 2017; Rini \& Sarah, 2014; Heriningsih \& Marita, 2013).

Building upon this conflicting perceivable tendency and the empirical findings from previous research, this paper provides a new approach to seek and confirm the opportune relationship between the quality of public financial management and corruption in Indonesia. We investigate the long-run nexus and verify the causality relation between the quality of public financial management and corruption in Indonesia.

The paper is organized as follows; Section 2 reviews the literature on the link between the quality of financial management and audit opinions, and their theoretical connection with corruption, while also discussing the previous empirical studies into this issue. Section 3 discusses the data and variable selection and the methods employed to answer the objectives of this research. Section 4 presents the empirical results and a discussion of the results. Section 5 will conclude the paper.

\section{LITERATURE REVIEW}

\section{Linkages between Public Financial Management, Audit and Corruption}

Defining PFM is challenging since there is no uniform definition for it. Erasmus and Visser (2002) define PFM as the activities and other functions of public servants that allow them to determine the optimum way to use limited resources to achieve the stated political goals effectively. Lawson (2015) explained public financial management as the set of laws, rules, and systems and processes to allocate and distribute revenue and public funds, undertake public expenditure, and account for the funds and audit results. These definitions suggest that public financial management is related to the overall budgeting process, from the budget's formation to its execution, accounting, reporting, and external audit.

As part of the management process, auditing is a crucial tool for assessing the overall performance quality of the management in managing their resources. An audit is needed by stakeholders to measure the performance of an entity. "The benefit of an audit is that it provides assurance that management has presented a 'true and fair' view of a company's financial performance and position. An audit underpins the trust and obligation of stewardship between those who manage a company and those who own it or otherwise have a need for a 'true and fair' view, the stakeholders." (PWC, 2017).

Sukrisno (2004) stated that an audit is a systematic and critical examination of the financial reports that have been prepared by management, along with accounting records and other relevant evidence, carried out by an independent party who are able to give an opinion about the fairness of the financial statements. An audit should be carried out by an independent, competent and objective party. 
Dye (2007) argued that an audit is useful to measure, report, and monitor a program's performance. The output of the audit is a report that contains the auditor's opinion of the fairness of the audited entity's reports. An audit comparing financial transactions is ca rried out according to set provisions, and reported according to the applicable reporting standards, so the opinion given by the auditor can be an adequate indicator of the quality of the financial management and the presentation of the financial statements.

An audit's opinion reflects the quality of the financial management of an organization; financial management that violates the existing rules and standards will be captured in the auditor's reports. The degree of the quality of good governance in managing public resources can be assessed to what extend the financial reports has fulfilled the accountability, full disclosure or transparency principles (Safkaur $e t$ $a l, 2019$ ).

Auditors are the representatives of the public's interests, they monitor and report managements' compliance with standards and criteria, and they are expected to participate in the fight against corruption (Jeppesen, 2019). Corruption can be found in any environment where the holders and wielders of power have no accountability (Klitgaard, 2001). The absence of accountability will lead to corruption, and the relationship between corruption and accountability is inversely proportional. An audit is also one of the pillars of the national integrity system to protect against corruption (Dye and Stapenhurst, 1998).

Sound financial management is expected to support the prevention and detection of fraudulent practices, the misuse of resources, and abuses of authority. Shihata (1997) asserted that a well organized financial management system, involving professional and punctual record keeping, auditing and performance supervision, is an effective tool to reduce corruption. Tanzi (1998) argued that strong auditing institutions are needed to discourage and detect corrupt activities. Moreover, Baswir (2000) said that through the development of accountability and transparency, opportunities for corruption can be reduced to the lowest level.

However, Dye (2007) stated that although financial audits sometimes reveal fraud, they are not designed to do so and there is a high expectation for the supreme audit institutions (SAIs) to develop strategies to detect fraud, even though public sector auditors have a responsibility, to a certain extent, to prevent and detect corruption. Meanwhile, Jeppesen (2019) argued that auditing's role in combating corruption has been hesitant, so far.

\section{Measuring Corruption}

The legal definition of corruption varies from country to country, and the are some competing definitions of corruption (Johnston, 1996; Rothstein \& Varraich, 2017) but the most widely cited definition of public sector corruption is from Johnston (1996) who defines corruption as the abuse of public office, power, or resources for private gain.

The lack of consensus on the definition of corruption makes it difficult to measure. Corruption is also a complex concept of collective practices. Thus, corruption can only be measured indirectly. There are some methods to measure corruption. The most widely used indicator to measure the level of corruption is the Corruption Perception Index (CPI), a composite index to quantify people's impression of corruptions practices in public service. The CPI also measures a broad range of practices; therefore it can measure corruption with a more comprehensive approach. It is also a reliable proxy for measuring corruption because of its 
robust methods and its ability to be compared with other proxies from time to time and between countries or regions. Nevertheless, since it measures only the perception of corruption, it is different from corruption per se, and perception can be affected by the political system, the degree of freedom the press have, and even income (Sharafutdinova, 2010).

\section{Empirical Evidence}

The empirical evidence of the linkages between auditing and corruption are presented by several studies. Farooq and Shehata (2018) studied the ability of external auditing to combat corruption, their study of private firms found that the firms with audited financial statements paid significantly lower bribes compared to firms without an audit. Neu, Everett and Rahaman (2011) investigated auditing's role on corruption in the public sector for the case of the Canadian Sponsorship Program, and found that fraud and corruption could occur within the public sector, even in the presence of seemingly robust controls.

The independence of the audit and its integrity and professionalism could reduce the level of corruption in a country (Gustavson \& Sunstrom, 2016) and this seems to be true for the private sector as well. The ratio of the number of auditors to the general population (Kimbro, 2002), and the number of accounting firms (Malagueno, Albrecht, Ainge, \& Stephens, 2010) and the considerable requirements of financial reporting (Khalil, Saffar, \&Trabelsi, 2015) could curb the level of perceived corruption. In the meantime, contradictory findings are discovered by some studies carried out in Indonesia, including those by Tehupuring in 2018, Rini and Sarah in 2014, and Heriningsih and Marita in 2013.

Heriningsih and Marita (2013) studied the impact of financial performance and audit opinions on corruption in 13 cities and regencies in Java, for the period from 2008 to 2010, and found that financial performance (gauged by the independency ratio, activity ratio, and growth) and the audit opinion have no effect on corruption.

Rini and Sarah (2014) examined the relationship between corruption at the regency level and the quality of the financial reporting (with the audit opinion as the proxy) in Indonesia for the year 2011, and the results of this study revealed that the quality of financial reporting improved, as indicated by the progress of the audit opinion's acquisition upon the Local Government Financial Statement (LKPD) in Indonesia. The second discovery shows there is no relation between the opinion given by the Audit Board of Indonesia (ABI) and the disclosures in a district's financial statement. The third finding shows that corruption in Indonesian is showing an increasing trend. The last, the disclosure of financial statements and audit opinions do not have an association with the level of corruption in Indonesia.

The analysis of the impact of audit opinions, audit findings, and audit rectification on the level of corruption in provincial governments was conducted by Rini and Damiati in 2017. This research employed a panel data regression with 18 provinces for the period from 2011 to 2014. The results show that both audit findings and audit opinions do not affect the level of corruption.

The most recent study by Tehupuring in 2018 investigated the relationship between an unqualified opinion and the level of corruption by employing the triangulation approach, which is a mixture of the qualitative and quantitative approaches where the quantitative approach used a correlation test, and concluded that from 31 provinces in Indonesia, an unqualified opinion representing the good governance of a province 
does not guarantee it is corruption-free, and this unqualified opinion does not significantly relate to the level of corruption.

\section{METHOD, DATA, AND ANALYSIS}

\section{Data}

This paper employs panel data from 10 cities in Indonesia from 2006 to 2017. The first variable is the Corruption Perception Index (CPI) taken from Transparency International Indonesia (TII) and the second variable is the audit opinion, obtained from the Audit Board of Indonesia (BPK RI). Table 1 explains the definition of the variables used in this study.

The Corruption Perception Index is a composite index of 32 types of questions related to corrupt practices. The 32 questions are categorized into five main categories: prevalence of corruption, public accountability, motivation for corruption, sectors affected by corruption, and the effectiveness of eradicating corruption. The average value of the five categories is the Indonesian Corruption Perception Index score. In Indonesia, CPI data were taken from 11 cities surveyed by Transparency International Indonesia (TII) in 2006, 2008, and 2010-2017. The survey was chosen based on certain criteria (purposive sampling) to get a representative sample according to the specified criteria. These criteria are determined as follows:
1. The Transparency International Indonesia (TII) Corruption Perception Survey was conducted in 11 cities in Indonesia. The 11 cities were Pekanbaru, Semarang, Banjarmasin, Pontianak, Makassar, Manado, Medan, Padang, Bandung, and Surabaya, and North Jakarta. The selection of 11 cities was based on the following considerations: First, the provinces in which surveyed cities are located make the largest contribution to the nation's gross domestic product (GDP); they account for almost 70 percent of GDP. Second, the 11 cities were chosen by considering the distribution of economic activities according to zoning or regional methods; namely the western, central and eastern parts of Indonesia.

2. Referring to the city sample examined by Transparency International Indonesia (TII), this study only used 10 samples of the cities or regional governments that had obtained opinions from the BPK on their Local Government Financial Reports (LKPD) for the period 2006-2016. North Jakarta was deliberately excluded because the survey conducted by TII included public services organized by ministries/institutions which are central government agencies, while the audit opinion given by the BPK was for DKI Jakarta Province's Regional Financial Report, thus the CPI for North Jakarta is irrelevant.

Table 1. Definition of Variables

\begin{tabular}{|c|c|c|}
\hline Variable & Description & Unit \\
\hline $\begin{array}{l}\text { Audit Opinion } \\
\text { (AO) }\end{array}$ & $\begin{array}{l}\text { Acquisition of audit opinion from } \\
\text { the BPK after the audit has been } \\
\text { conducted, to measure the quality } \\
\text { of public financial management. }\end{array}$ & $\begin{array}{l}\text { - Unqualified opinion, ranked } 4 \text { (1-4 point scale). } \\
\text { - Qualified opinion, ranked 3 (1-4 point scale). } \\
\text { - Qualified opinion with an explanatory paragraph, } \\
\text { ranked } 2.5 \text { (1-4 point scale). } \\
\text { - Adverse opinion, ranked } 2 \text { (1-4 point scale) } \\
\text { - Disclaimer of opinion, ranked 1 (1-4 point scale) }\end{array}$ \\
\hline $\begin{array}{l}\text { Corruption } \\
\text { Perception Index } \\
\text { (CPI) }\end{array}$ & $\begin{array}{l}\text { The CPI is an index number used } \\
\text { to measure the level of the } \\
\text { perception of corruption, as a } \\
\text { proxy of corruption. }\end{array}$ & $\begin{array}{l}\text { The Corruption Perception Index (CPI) is measured } \\
\text { on a scale of } 1-100 \text {, If the index is closer to } 100 \text {; the } \\
\text { level of corruption is low. }\end{array}$ \\
\hline
\end{tabular}


While the audit opinion is an opinion given by the auditor after examining the submitted financial statements using predetermined standards. The financial statements should provide sufficient evidence, and ensure adequate internal control systems and must be in accordance with the applicable laws and regulations. The unqualified (WTP) opinion is the best possible audit outcome, followed by qualified (Wajar Dengan Pengecualian/WDP) as the second-best, and disclaimer as the worst.

\section{Data Analysis Method}

To investigate the long-run relationship between the quality of public financial management and corruption, this study employs econometric testing for the time series data. A panel unit root test is run to verify the stationarity of the variables' data and continued with a cointegration analysis to confirm the long-run relationship. To validate the causality relationship for both variables, this study applied the standard Granger causality test.

\section{Panel Unit Root Test}

The empirical examination in this paper employs standard panel unit root tests such as: Levin-LinChu (LLC) test, Im-Pesaran-Shin (IPS) test, and the Fisher-ADF test and Fisher PP test for nonparametric unit roots. Panel data increases the power of a unit root test on individual time series data.

Firstly, suppose that the first-order auto regressive model $\mathrm{AR}(1)$ for the panel data is as follows:

$$
\mathrm{Y}_{\mathrm{it}}=\rho_{\mathrm{i}} \mathrm{Y}_{\mathrm{it}-1}+\mathrm{u}_{\mathrm{it}} \quad-1 \leq \rho \leq 1
$$

where $u_{i t}$ is a white noise error term, and $i=1,2$, ...., $\mathrm{N}$ is a cross-section series that was observed over period $t=1,2, \ldots, \mathrm{T}$. For any individual trends and fixed effects, $\rho_{i}$, the autoregressive coefficients, and the errors, $\varepsilon_{i t}$, are assumed to be mutually independent idiosyncratic (individual specific) disturbances. If $\left|\rho_{i}\right|<1, Y_{i t}$ it means that the series is stationary. On the other hand, if $\left|\rho_{i}\right|$ $=1$, then $Y_{i t}$ contain a unit root.

In the case of a non-stationary series, running an OLS regression and hypothesis testing for $\rho$ using the usual $t$ test will result in a severe spurious regression; therefore we can manipulate this by subtracting both sides with $Y_{i t-1}$, to obtain:

$$
\Delta \mathrm{Y}=\theta \mathrm{Y}_{\mathrm{it}-1}+\mathrm{u}_{\mathrm{it}}
$$

where $\Delta$ is the first difference operator and $\theta=$ $(\rho-1)$. To allow for the various possibilities, the unit root test is estimated in two forms; with intercept:

$$
\Delta \mathrm{Y}=\beta_{1}+\theta \mathrm{Y}_{\mathrm{it}-1}+\mathrm{u}_{\mathrm{it}}
$$

and with intercept and trend:

$$
\Delta \mathrm{Y}=\beta_{1}+\beta_{2} \mathrm{t}+\theta \mathrm{Y}_{\mathrm{it}-1}+\mathrm{u}_{\mathrm{it}}
$$

where $t$ is the trend variable and tests the null hypothesis $\left(\mathrm{H}_{0}\right) \theta=0$ (if there is a unit root), and the alternative hypothesis, $\left(\mathrm{H}_{\mathrm{A}}\right) \theta<0$ (the series is stationary).

\section{Cointegration Test}

Secondly, panel cointegration tests are performed in the case where the time series are non-stationary (at level), to determine whether the between-variables have a stable, long-run relationship (Pedroni, 2004).

The basic idea of the Engle-Granger (1987) cointegration test is for when two variables are in disequilibrium in the short-run, but those two variables may be cointegrated (long-run relationship) if the error term or equilibrium term is stationary at levels $I(0)$. Pedroni and Kao (1999) extend that Engle-Granger cointegration test's framework for pooled data.

The Pedroni panel cointegration tests consist of two types: a panel cointegration test and the 
group mean panel cointegration test. The first test is based on the "within dimension" approach, which includes the following statistics: Panel-v, Panel-rho, Panel-ADF and Panel-PP. The second is based on the "between dimension" approach, which includes; Grouprho, Group-PP and Group ADF (Pedroni, 2004; Mahadevan and Asafu-Adjaye, 2007). It is commonly accepted that the Panel-ADF is more reliable since it has better small sample properties than the other statistics. In the following regression:

$$
\mathrm{y}_{\mathrm{it}}=\alpha_{\mathrm{i}}+\delta_{\mathrm{i}} \mathrm{t}+\beta_{1 \mathrm{i}} \mathrm{x}_{1 \mathrm{i}}+\beta_{2 \mathrm{i}} \mathrm{x}_{2 \mathrm{i}}+\ldots+\beta_{\mathrm{Mi}} \mathrm{x}_{\mathrm{Mit}}+\mathrm{e}_{\mathrm{it}}
$$

where $t=1,2, \ldots, T$; and $i=1,2, \ldots, N ; m=1$, $2, \ldots, M$; and assume that variables $y$ and $x$ are integrated of an order one $I(1)$. The $\alpha_{i}$ and $\delta_{i}$ are individuals, and the trend effects parameters, if desired, can be set to zero.

Under the null hypothesis, the residuals are not stationary or there is no cointegration, the error terms, $e_{i t}$, will be integrated at an order one $I(1)$. The method is to obtain the residuals from the equation above and then running the regression to test whether the error terms are $I(1)$ :

$$
\mathrm{e}_{\mathrm{it}}=\rho_{\mathrm{i}} \mathrm{e}_{\mathrm{it}-1}+\mathrm{u}_{\mathrm{it}} .
$$

Pedroni proposed several methods of constructing statistical testing for a null hypothesis or where there is no cointegration $\left(\rho_{i}=1\right)$. There are two alternative hypotheses, $\left(\rho_{i}=\rho\right)=1$ for all $I$ (homogenous alternative, within-dimension test or panel statistics test) and $\left(\rho_{i}=\rho\right)=1$ (the homogenous alternative, within-dimension test or panel statistics test), and $\rho_{i}<1$ for all $i$ (heterogeneous alternative, between-dimension or group statistics test).

From both the equations above we can construct the Pedroni panel cointegration statistic $\xi_{\mathrm{N}, \mathrm{T}}$. The Pedroni asymptotically normally distributed standardized statistic is:

$$
\frac{\xi N, T-\mu \sqrt{N}}{\sqrt{u}}=\mathrm{N}(0,1)
$$

where $\mu$ and $\mathrm{v}$ are Monte Carlo-generated adjustment terms. Details of tests are provided in the original papers, Pedroni (2004).

\section{Causality Test}

Lastly, to confirm the existence of a causality relationship between both variables, the next step was to examine the causality test by performing the Granger causality test. It is important to note that the correlation between variables does not necessarily imply a causation relationship. The conclusion of a true causality relationship should come from a priori, a statistical test for causality such as the Granger causality test can only show "predictive causality" based on the assumption that one occurrence preceding another can be valid proof of a causation relation (Gujarati, 2009).

The approach of the Granger causality test to the question of whether $x$ causes $y$, or the other way around, to see how much the past value of $y$ $\left(y_{t-k}\right)$ can explain the current value of $y\left(y_{t}\right)$ and then to check whether adding lagged values of $x$ $\left(x_{t-k}\right)$ can help to improve the explanation of $y$. If $x$ improves the ability to predict the value of $y$, then, $x$ is concluded to be the cause of $y$ because of Granger, or in other words, if the lagged $x$ 's coefficients are statistically significant (and bidirectional causation is often the case); $x$ Granger-causes $y$ and $y$ Granger-causes $x$.

The models for the bivariate regression are specified as follows:

$$
\begin{aligned}
& y_{t}=\sum_{i=1}^{n} \alpha_{i} x_{t-i}+\sum_{j=1}^{n} \beta_{j} y_{t-j}+u_{1 t} \\
& x_{t}=\sum_{i=1}^{n} \lambda_{i} y_{t-i}+\sum_{j=1}^{n} \delta_{j} x_{t-j}+u_{2 t}
\end{aligned}
$$

For all possible $(x, y)$ series pairs of ( $x$ and $y$ ) in the group. The F-statistics-calculated are the Wald statistics for the joint hypothesis:

$$
\beta_{1}=\beta_{2}=\ldots=\beta_{\mathrm{j}}=0
$$

for each equation. For the first regression under 
a null hypothesis, $x$ does not Granger-cause $y$ and the second regression shows that $y$ does not Granger-cause $\mathrm{x}$.

\section{EMPIRICAL RESULTS}

\section{Panel Unit Root Test}

It is suggested to investigate the existence of unit roots in all the variables before proceeding to any econometrics analysis, to avoid spurious regression results, by employing the classical ordinary least square (OLS) estimator. Table 2. provides the result of the unit root test for with and without a trend term. From the results it can be seen that both variables are not stationary at level, but after taking the five percent significance level at the first difference, both variables become stationary in most of the unit root tests (except LLC test for opinion variable at the first difference by intercept). This result indicates that both the Corruption Perception Index (CPI) and audit opinions were integrated at order one, $I(1)$.

From the results we can conclude that both variables are non-stationary at levels, $I(0)$, and become stationary in most tests at the first difference, $I(1)$. This conclusion is important as a precondition before proceeding to the next step of the panel cointegration test, since we suspect there is a long-run relationship.

\section{Panel Cointegration Test}

When the series are integrated in the same order, one can proceed with the cointegration test. Table 3. shows the results of the panel cointegration test.

Table 3 above shows the results of all the panel cointegration tests when the dependent variable is the CPI and the explanatory variable is the audit opinion. There are two parts in Table 3 above, the first four tests' statistics are computed by the "within" dimension (panel statistics) and the last three tests' statistics are computed by the "between" dimension (group statistics). If the null hypothesis is rejected, then the CPI is cointegrated with audit opinions. From the results, most of the estimation results of the Pedroni's panel cointegration tests indicate that the null hypothesis of no cointegration can be rejected at the one percent significance level, for using either the intercept or the intercept with trend.

Table 2. The Result of Panel Unit Root Test ${ }^{*}$ )

\begin{tabular}{|c|c|c|c|c|c|}
\hline \multicolumn{6}{|c|}{ At Levels } \\
\hline \multirow{3}{*}{ Intercept } & Variable & LLC & IPS & Fisher-ADF & Fisher-PP \\
\hline & Opinion & $-7.41 *$ & -1.59 & $30.45^{* *}$ & 25.37 \\
\hline & CPI & -1.59 & 1.25 & 13.79 & 19.20 \\
\hline \multirow{2}{*}{$\begin{array}{l}\text { Intercept and } \\
\text { Trend }\end{array}$} & Opinion & $-8.78 *$ & -1.06 & $32.79 * *$ & $50.05 *$ \\
\hline & CPI & $-2.60 *$ & 0.55 & 20.35 & $55.11 *$ \\
\hline \multicolumn{6}{|c|}{ First Difference } \\
\hline \multirow{2}{*}{ Intercept } & Opinion & 1.26 & $-1.69 * *$ & $20.61 * *$ & 78.02* \\
\hline & CPI & $-3.78 *$ & $-2.02 * *$ & 40.03* & 97.81* \\
\hline \multirow{2}{*}{$\begin{array}{l}\text { Intercept and } \\
\text { Trend }\end{array}$} & Opinion & 0.96 & 0.00 & 16.05 & 81.86* \\
\hline & CPI & $-7.3^{*}$ & 0.98 & $35.57 *$ & 08.65* \\
\hline
\end{tabular}

${ }^{7}$ Note: Levin, Lin, and Chu test (LLC), Null Hypothesis: unit roots and Im, Pesaran, and Shin W-Stat test (IPS), ADF-Fisher Chi Square test (ADF-Fhiser), PP-Fisher Chi-Square test (PP), Null Hypothesis: unit root . The Null Hypothesis of LLC, IPS, Fisher-ADF, Fisher-PP tests examine for non-stationary items. **, and * indicate statistical significance at five percent and one percent respectively. 
Table 3. The Results of Pedroni's Residual Cointegration Test ${ }^{*}$

\begin{tabular}{ccc}
\hline & Intercept & Intercept and Trend \\
\cline { 2 - 3 } & t-statistic & t-statistic \\
\hline Within dimension & & \\
Panel v & 0.30 & -1.45 \\
Panel rho & $-\mathbf{3 . 0 5 *}$ & -1.30 \\
Panel PP & $-\mathbf{5 , 7 3 *}$ & $\mathbf{- 9 . 7 4 ^ { * }}$ \\
Panel ADF & $-\mathbf{5 . 9 7 *}$ & $\mathbf{- 9 . 9 5 *}$ \\
Between dimension & & \\
Group rho & 0.54 & 1.13 \\
Group PP & $-\mathbf{4 . 6 5 *}$ & $\mathbf{- 6 . 1 3 *}$ \\
Group ADF & $-\mathbf{5 . 1 0 *}$ & $\mathbf{- 6 . 9 1 *}$ \\
\hline *) Note: The null hypothesis is that the residuals are non-stationary, thus variables are not \\
cointegrated. *and ** indicate that the estimated parameters reject the null hypothesis \\
at the one percent and five percent levels. Newey-West bandwidth selection using \\
Bartlett Kemel Cross Method Statistic Prob.
\end{tabular}

This displays that the changes in the CPI are related to the audit opinion variable in the longrun in those 10 cities. However, the results show a degree of inconsistency; some statistics are significant, but there are some exceptional results, such as the panel $\mathrm{v}$ and Group rho in estimation with intercept, and panel $\mathrm{v}$ and rho and Group rho in estimation with intercept and trend. Some of the literature says that in Pedroni's cointegration test panel ADF and Group ADF are the most important, and in our result, both tests are seen to be statistically significant at $\alpha=1 \%$. It is important to note that, from an economics perspective, it is hard to determine how long a long-run is, but most economists agrees that a long-run is the period of time in which a variable may vary. In accounting, a long-run is mostly associated with a period of time that is more than one fiscal term (one year). To make this abstract concept of a long-run clear, the term long-run can be interpreted in this paper as the behavioral change of a public institution due to it having a regular audit.

\section{Causality Test}

The literature states that, with cointegration testing, if there is a long-run relationship between variables, a causality relationship must exist in at least one direction. In Table 4, the results of the Granger causality test show there is empirical evidence of one-directional causality between audit opinion and CPI variables. The result shows that audit opinion Granger causes CPI, but does not apply the other way around.

Table 4. Pairwise Granger Causality Test Results

\begin{tabular}{llc}
\hline \multicolumn{1}{c}{ Null Hypothesis } & F-Statistic & Prob. \\
\hline $\begin{array}{l}\text { Audit opinion does not } \\
\text { Granger-cause CPI }\end{array}$ & 7.75501 & $\mathbf{0 . 0 0 0 9}^{*}$ \\
CPI does not Granger-cause & 2.68288 & 0.0750 \\
audit opinion & & \\
\hline *) Note: The null hypothesis is there is no causality \\
between audit opinion and CPI respectively. For \\
cases with probability levels lower than 0.05 , we \\
cannot accept a null hypothesis.
\end{tabular}

\section{DISCUSSION}

The results above confirm strong and significant empirical evidence of the long-run relationship between audit opinion and corruption level. This result vindicates the previous research done by Neu, Everett and Rahaman (2011), Gustavson and Sunstrom (2016), Malagueno, et al (2010), Khalil et al (2015) and does not support the findings of the studies carried out in Indonesia by Tehupuring (2018), Rini and Damiati (2017), 
Rini and Sarah (2014), and Heriningsih and Marita. (2013).

We argued that the competing results found in this paper and the previous studies conducted in Indonesia are due to the proxy variables selected for use and the methods employed. The proxy variables for audit opinion or corruption in the previous papers are suspected of having no stationary properties. The audit opinion, CPI and corruption cases have increased over time (time variant), thus the application of a linear regression (Rini and Damiati (2017), Rini \& Sarah (2014), and Heriningsih \& Marita (2013)) for non-stationary data could lead to spurious parameter estimations. The application of correlation testing with a dichotomous variable (binary variable or categorical variable) in the paper by Tehupuring (2018) cannot express a causal relationship. Moreover, a proxy variable for corruption with data related to the number of corruption cases arguably leads to a biased proximity. For illustration, in areas with high degrees of corruption, it is possible that collusion between law enforcement agents and the corrupt actors is taking place; as a consequence, the number of corruption cases can be very low, even though fraudulent practices occur almost daily.

The result of cointegration and causality testing in this paper indicates that the quality of public financial management and corruption in Indonesia have a long-run relationship, and the quality of public financial management has the ability to cause future corruption; when the audit opinion is improved the corruption will reduce (the value of CPI is increasing).

The long-run relationship prevails as a result of the consistent and independent audits to prevent and detect corruption. In Indonesia, the Audit Board of Indonesia(BPK-RI) is equipped with the authority to prevent and detect corruption. Auditing has helped the GoI to identify the areas in which it is exposed to the risk of corrupt and fraudulent practices, and an independent audit encourages those responsible for internal control to exercise their duty and initiate the monitoring system to prevent corruption through feedback and suggestions (Jeppesen, 2019). Auditors are also in a position to prevent the GoI from issuing laws and regulations that would allow them to run the public office corruptly.

The detection of corruption by auditors also has a significant impact on the behavior of public servants, by deterring them from being involved in corrupt practices (Wells, 2002). This also encourages politicians to avoid committing fraudulent activities to avoid losing their elected positions (Ferraz \& Finan, 2011), thus this discourages political corruption.

The auditing of financial statements also encourages transparency and accountability in the management of public finances. An audit also effectively promotes efficiency and good governance and assists the GoI to improve the business processes of public institutions. In the long-run, consistent financial auditing will affect the attitude of public servants in their management of the taxpayers' money and encourage them to be more aware of how public money should be managed. Furthermore, auditing can create a constant vigilant environment that enhances risk and creates a lesser pay-off for any fraudulent or corrupt practices. Consistent, scheduled and systematic audits and controls also signal the GoI's commitment to improving good governance and management of the public finances.

\section{CONCLUSION}

In conclusion, the quality of public financial management has long run effect on corruption level, through the process of behavioral and institutional changes in the public sectors. A 
sound public financial management could gradually shift the attitude of public officers toward corrupt and fraudulent practices and encourage the improvement of standards, regulation, procedure and overall institutional aspects that can reduce the opportunity to abuse the power or authority for private benefit. Notwithstanding, the behavioral and institutional changes are needed to be further studied.

Regarding that, as a recommendation, the GoI should continue its commitment to improve the management of public finances. The Audit Board of Indonesia (BPK-RI) is expected to strengthen its control and supervision function through improvements to the methods, capacity, and integrity of auditors, to enhance their capabilities to prevent and detect any misconduct in the future.

\section{REFERENCES}

Brown, R. A. (2006). Indonesian corporations, cronyism, and corruption. Modern Asian Studies, 40(4), 953-992.

Dorotinsky, W., \& Pradhan, S. (2007). Exploring corruption in public financial management. The many faces of corruption, 267.

Dye, Kenneth M. (2007). Corruption and fraud detection by public sector auditors. EDPAC: The EDP Audit, Control, and Security Newsletter, 36(5-6), 6-15.

Dye, Kenneth \& Stapenhurst, Rick. (1998). Pillars of Integrity: The Importance of Supreme Audit Institutions in Curbing Corruption. WBI Working Papers. Washington, DC: World Bank.

http://documents.worldbank.org/curated/en/ 199721468739213038/Pillars-of-integritythe-importance-of-Supreme-AuditInstitutions-in-curbing-corruption

Erasmus, P. W., \& Visser, C. B. (2002). The management of public finance: A practical guide. OUP Catalogue.

Farooq, O., \& Shehata, N. F. (2018). Does external auditing combat corruption?
Evidence from private firms. Managerial Auditing Journal.

Ferraz, C., \&Finan, F. (2011). Electoral accountability and corruption: Evidence from the audits of local governments. American Economic Review, 101(4), 12741311.

Gujarati, D.N. (2009) Basic Econometrics. Tata McGraw-Hill Education, New Delhi.

Gustavson, M., \&Sundström, A. (2016). Organizing the audit society: Does good auditing generate less public sector corruption? Administration \& Society, 50(10), 1508-1532.

Heriningsih, S., \& Marita, M. (2013). Pengaruh Opini Audit dan Kinerja Keuangan Pemerintah Daerah terhadap Tingkat Korupsi Pemerintah Daerah (Studi Empiris pada Pemerintah Kabupaten dan Kota di Pulau Jawa). Jurnal Manajemen, Akuntansi dan Ekonomi Pembangunan, 11(1), 67-78.

Jeppesen, K. K. (2019). The role of auditing in the fight against corruption. The British Accounting Review, 51(5), 100798.

Johnston, M. (1996). The search for definitions: the vitality of politics and the issue of corruption. International social science journal, 48(149), 321-335.

Kao, C.(1999). Spurious regression and residualbased tests for cointegration in panel data, Journal of Econometrics, 90, pp.1-44.

Khalil, S., Saffar, W. \& Trabelsi, S. (2015). Disclosure Standards, Auditing Infrastructure, and Bribery Mitigation. Journal of Business Ethics 132, pp. 379-399. https://doi.org/10.1007/s10551-014-2321-6

Kimbro, M. Barros. (2002). A Cross-Country Empirical Investigation of Corruption and its Relationship to Economic, Cultural, and Monitoring Institutions: An Examination of the Role of Accounting and Financial Statements Quality. Journal of Accounting, Auditing \& Finance. Volume: 17 issue: 4, page(s): 325-350.

Lawson, A .2015. Public Financial Management. GSDRC Professional Development Reading 
Pack no. 6. Birmingham, UK: GSDRC, University of Birmingham.

MacMillan, Joanna. (2011). Reformation and Public Corruption: Why Indonesia's AntiCorruption Agency Strategy Should Be Reformed to Effectively Combat Public Corruption. Emory International Law Review. Vol. 25, Issue 1.

Mahadevan, R., Asafu-Adjaye, J., 2007. Energy consumption, economic growth and prices: reassessment using panel VECM for developed and developing countries. Energy Policy 35, 2481-2490.

Malagueño, R., Albrecht, C., Ainge, C., \& Stephens, N. (2010). Accounting and corruption: a cross-country analysis. Journal of Money Laundering Control.

Neu, D., Everett, J., \& Rahaman, A. (2013). Auditing and corruption in the public sector: The case of the Canadian Sponsorship Programme. Contemporary Accounting Research, 30(3), 1223-1250.

Pedroni, P. (2004). Panel cointegration: asymptotic and finite sample properties of pooled time series tests with an application to the PPP hypothesis. Econometric theory, 20(3), 597-625. Retrieved from https://web.williams.edu/Economics/pedroni /pc-revc.pdf.

Rini, R., \& Damiyati, L. (2017). Analisishasil audit pemerintahan dan tingkat korupsi pemerintahan provinsi di indonesia. Jurnal Dinamika Akuntansi dan Bisnis, 4(1), 73-90.

Rini, R., \& Sarah, A. (2014). Opini audit dan pengung kapan atas laporan keuangan pemerintah kabupaten sertakaitannya dengan korupsi di Indonesia. Etikonomi, 13(1).
Safkaur, Otniel \& Afiah, Nunuy \& Poulus, Sugiono \& Dahlan, Muhammad. (2019). The Effect of Quality Financial Reporting on Good Governance. International Journal of Economics and Financial Issues. 9. 277286. 10.32479/ijefi.8047.

Sharafutdinova, G. (2010). What explains corruption perceptions? The dark side of political competition in Russia's regions. Comparative Politics, 42(2), 147-166.

Shihata, Ibrahim F.I. (1997). Corruption-A General Review With an Emphasis on the Role of the World Bank. Penn State International Law Review, Vol. 15: No. 3, Article 2. Available at: http://elibrary.law.psu.edu/psilr/vol15/iss3/2

Sukrisno, A. (2004). Auditing (Pemeriksaan Akuntan) oleh Kantor Akuntan Publik. Edisi Ketiga Penerbit Fakultas Ekonomi Universitas Trisakti.

Tanzi, Vito. (1998). Corruption Around The World: Causes, Consequences, Scope, and Cures. Internanational Monetary Fund Working Paper No. 98/63.

Tehupuring, Ronald. 2018. Unqualified opinion and level of corruption: the triangular approach. Jurnal Tata Kelola \& Akuntabilitas Keuangan Negara Vol 4, No. 2, pp. 187-206.

Wells, J. T. (2002). Let them know someone's watching. Journal of Accountancy, 193(5), 106.

, Price Waterhouse Cooper (PWC). 2017. Understanding a Financial Statement Audit. PWC Report.

, Badan Pemeriksa Keuangan RI, 20062017. Ihtisar Hasil Pemeriksaan Sementara Semester I dan II Tahun 2006-2017. 